\title{
Impact of moderate-intensity aerobic exercise training on sleep quality and cardiac structure and function in inactive obese girls
}

\author{
Tartibian B ${ }^{1}$, Ejlali $\mathbf{M}^{2}$, Azadpour $\mathbf{N}^{3}$ \\ 1. Associate Professor of Exercise Physiology, Department of Sport Injuries and Corrective Exercises, Head of Core \\ Research of Health Physiology and Physical Activity, Faculty of Physical Education and Sport Sciences, Allameh Tabataba'i \\ University, Tehran, Iran. ORCID ID: 0000-0002-4653-5620 \\ 2. MSc of Exercise Physiology, Department of Exercise Physiology, Faculty of Sport Sciences, Urmia University, Urmia, \\ Iran. \\ 3. PhD of Exercise Physiology, Ardabil University of Medical Sciences, Ardabil, Iran (Corresponding Author), Tel: \\ +984533251681, no_azadpoor@yahoo.com, ORCID ID: 0000-0003-4005-6300
}

\begin{abstract}
Background and Aim: Aerobic exercise plays an important role in prevention of obesity, improvement of sleep quality and cardiovascular function. The purpose of this study was to investigate the effects of 8 weeks of moderate-intensity aerobic exercise training on sleep quality, and also cardiac structure and function in inactive obese girls.
\end{abstract}

Materials and Methods: In this study, 20 inactive obese girls (mean age; 18 year, mean BMI $\left.\geq 30 \mathrm{~kg} / \mathrm{m}^{2}\right)$ participated voluntarily and were randomly assigned to exercise $(\mathrm{E}, \mathrm{n}=10)$ and control $(\mathrm{C}, \mathrm{n}=10)$ groups. Exercise group participated in aerobic exercise program for 8 weeks (60 $\mathrm{min} /$ day, 3 times/week, 50\%-70\% maximal heart rate). Control group maintained their daily routine physical activity for 8 weeks. At baseline and after 8 weeks of the training program, both groups were evaluated for cardiac function and structure, and also sleep quality by use of echocardiography and sleep quality questionnaire respectively. T-test and Pearson correlation coefficient were used for data analysis. $\mathrm{p} \leq 0.05$ was considered significant.

Results: Sleep quality improved significantly in the exercise group compared to that in the control group $(\mathrm{p} \leq 0 / 05)$. Among cardiac structural and functional indices, only cardiac output significantly increased in exercise group compared to that in the control group $(\mathrm{p} \leq 0 / 05)$.

Conclusion: 8 weeks of moderate intensity aerobic exercise training improved sleep quality in inactive obese girls. However, except for cardiac output, it did not create any significant change in other cardiac structural and functional indices.

Keywords: Obese girls, Cardiac structural and functional indices, Sleep quality, Aerobic exercise

Received: Dec 31, $2018 \quad$ Accepted: August 3, 2019

How to cite the article: Tartibian B, Ejlali M, Azadpour N. Impact of moderate-intensity aerobic exercise training on sleep quality and cardiac structure and function in inactive obese girls. SJKU 2019;24(4):41-55.

Copyright (C) 2019 the Author (s). Published by Kurdistan University of Medical Sciences. This is an open access article distributed under the terms of the Creative Commons Attribution-Non Commercial License 4.0 (CCBY-NC), where it is permissible to download, share, remix, transform, and buildup the work provided it is properly cited. The work cannot be used commercially without permission from the journal. 


\section{تأثير تمرينات هوازى با شدت متوسط بر كيفيت خواب و ساختار و عملكرد قلب در دختر ان جاق غير فعال}

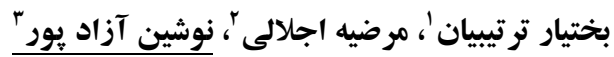

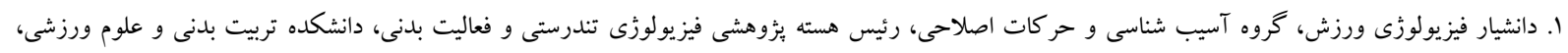

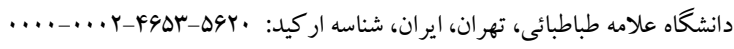

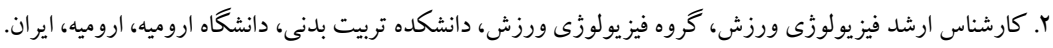

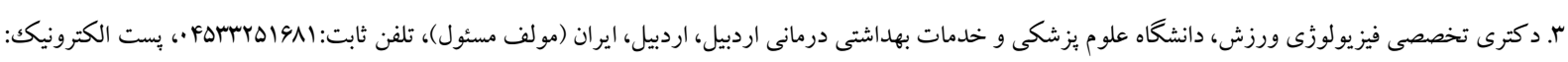

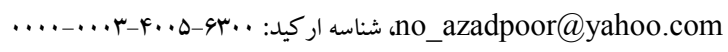

حצكيله

زمينه و هدف: ورزش هوازى نقش مهمى در ييشخيرى از خاقى، بهبود كيفيت خواب و ارتقاى عملكرد سيستم قلبى عروقى دارد.

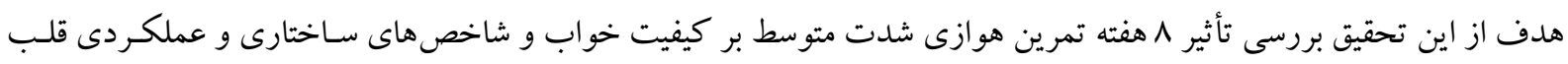
دختران جاق غير فعال بود.

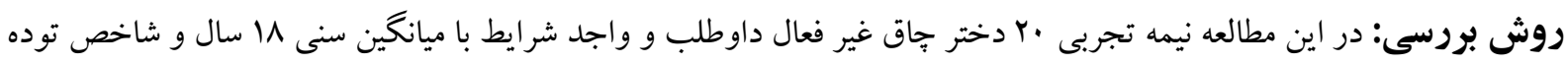

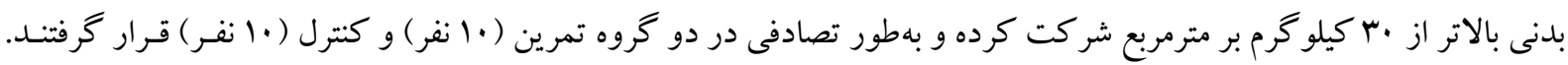

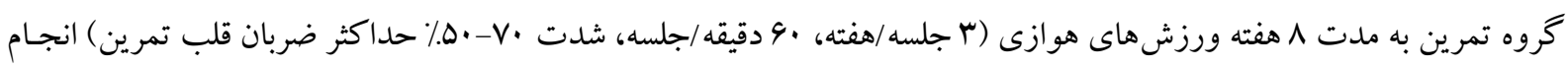

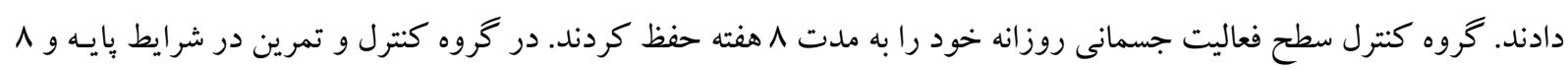

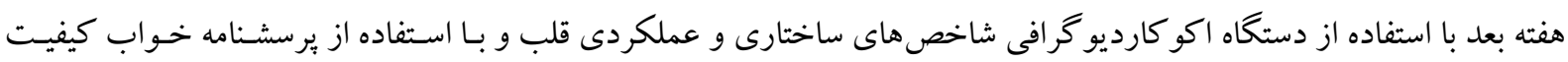

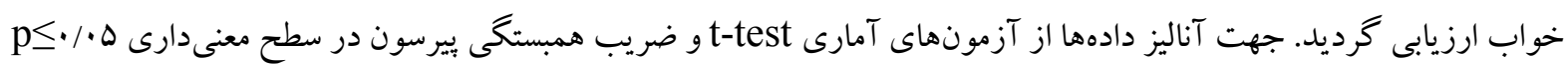
| استفاده گرديد.

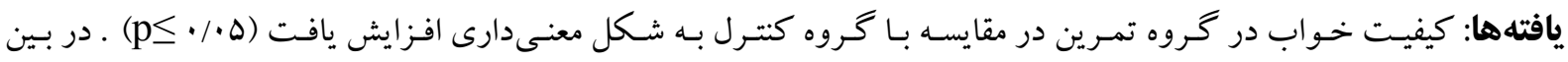

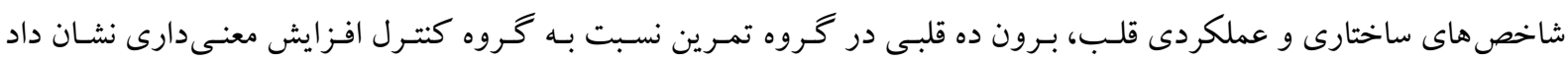

نتيجه كيرى: 1 هفته تمرين هوازى شدت متوسط در دختران جاق غير فعال باعث بهبود كيفيت خواب مى گردد. اما به غير از برون ده قلبى، تغييرات معنى دارى در ديخر شاخص هاى ساختارى و عملكردى قلب ايجاد نمى كند.

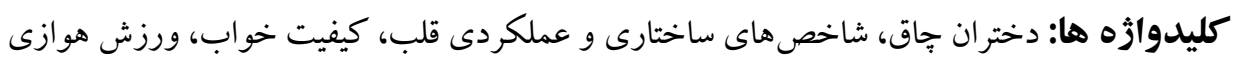

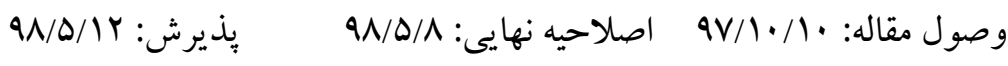


براى خوردن منجر به افزايش جذب كـالرى شـود. همجنـين محروميت از خواب به دليل ايجاد تغيير در تنظيم حـرارت و افزايش خستخى مى تواند هزينه انززى را كـاهش دهـد (Y) . علاوه بر اين، نتايج بهدست آمده از تحقيقـات آزمايشـاهى

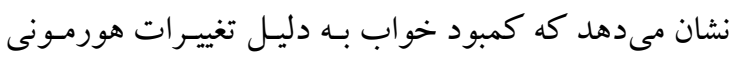
كه ايجاد مى كند ممكن است موجب افزايش جذب كـالرى و كاهش هزينه انرزى شده و درنهايت منجر به افزايش وزن كردد. از آنجايى كه خواب يكك تنظيم كننده مهـم عملكـرد

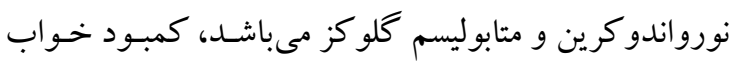

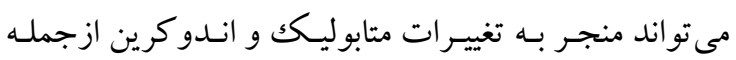
كاهش تحمل كلو كز و كاهش حساسيت انسولينى شده و بـا تغيير هورمونهاى تنظيم كننده اشتها ازجمله لٍتين و حرلين

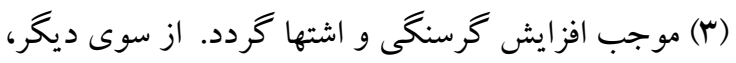

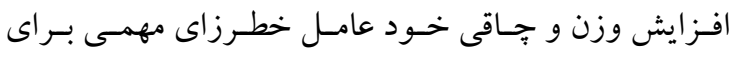
بسيارى از مشكلات مرتبط با سلامتى از قبيل ديابـت نـوع r، سرطان و مشكلات تنفسى به شمار مىرود. بهويزه تحقيقـات متعدد ثابت كردهاند كه جاقى يكك عامـل خطرز زاى مسـتقل براى بيمارىهاى قلبى عروقى ازجمله فشار خون بالا و سكته مىباشد. در عين حال، يزوهشهاى جديد وجود ارتباط مهم بسين اخستلالات خـواب و بيمـارىهـاى قلبى عروقى رانيـز كزارش نمودهاند. بهطورى كه بر آورد شده است كـه حسدود •ا درصد از جمعيت، اخـتلال خـواب تشـخيص داده نشـده دارند كه ممكن است علت زمينهاى ايجاد بيمارىهاى قلبى باشد . يكى از مكانيسمهاى مرتبط كننده اختلالات خواب با بيمارىهاى قلبى عروقى، بهواسطه تأثير آن بر فعاليت سيستم

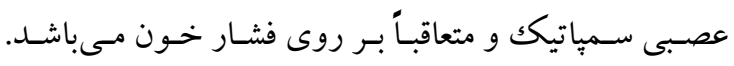
بطوريكـه بـر طبـق تحقيقـات انجـام شـده بيمـاران مبـتلا بـهـ اختلالات خواب كه فشار خون نرمال دارند در طى f سـال در معرض خطر توسعه فشار خون بالا قرار دارنـد، كـه خـود عامل خطرزايى براى بيمارىهاى قلبى ازجمله سكته به شمار مىرود. علاوه بر اين، مشخص كرديده كه اختلالات خواب حتى مستقل از جاقى نيز ممكـن اسـت تغيــرات سـاختارى و

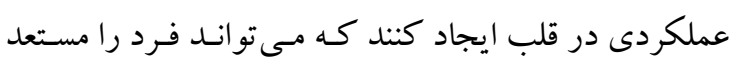
انسانها حدود يكك سوم دوران زنـدكى خـود را در خـواب

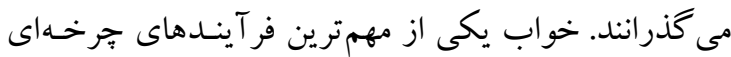
شبانهروزى است كه نقش زيادى در حفظ سلامت جسمى،

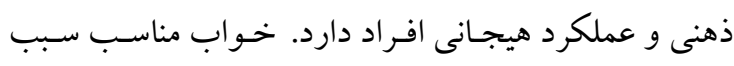
ارتقاء عملكرد سيستم ايمنى، تثبيت حافظه، تعـديل فر آينـد متابوليكى در سطح مولكولى و حفـظ كـاتكول آمسينهـا در مغز مى گردد و در باليدگى ارگانهاى بــدن نقـش مهمسى را

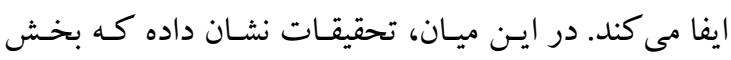
بزرخى از جمعيـت دنيـا دجهـار اخـتلالات خـواب هسـتند. اختلالات خـواب بـه وضعيت هـايى كفتـه مسىشـود كـه بـر توانايى خوب خوابيدن به طور منظم تأثير مى گذارد. اختلال خواب سبب مشكلات هورمونى، تضعيف عملكـرد سيستم ايمنى، تحريكك عوامل ييش التهابى و التهابى، افزايش خطر ابستلا بـه بيمـارىهـاى قلبى عروقى و اخـتلالات متابوليكك همانند جاقى مى گردد. تحقيقات متعـدد انجـام شـده در ايـن

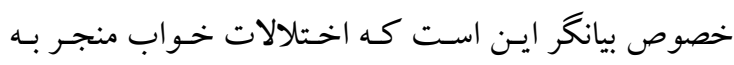

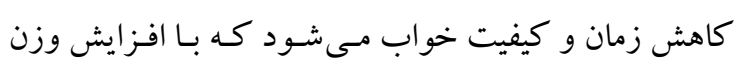
بدن و تجمع جربى همـراه اسـت (1). بـا توجـه بـه آمارهـاى جديد منتشر شده در اين زمينه مشخص كرديده است كه در طى جند دهه كذشته در جوامع مدرن كاهش مـدت خـواب در بزر كسالان و كود كان به مـوازات شـيوع كسترده جـاقى بـوده اسـت. بطوريكـه ثابـت شـده اسـت كـه بزر كسـالان و كود كانى كه خواب كمترى دارند در مقايسه با افر ادى كـه خواب كـافى دارنـد از وزن بيشـترى برخـوردار هسـتند (Y). هـمجزنـين جنــدين مطالعـه اييـدميولوزيكك نيـز ارتبـاط بـين شاخص توده بدنى بالاتر با كو تاه بودن زمـان خـواب را هـم در كود كان و هم در بزر گسالان اثبات كردهانـد. مكانيسمم -

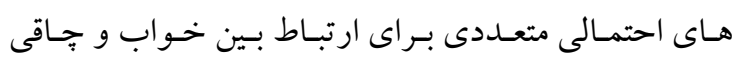

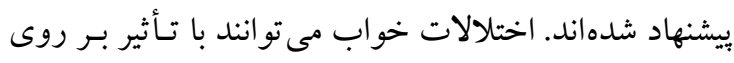

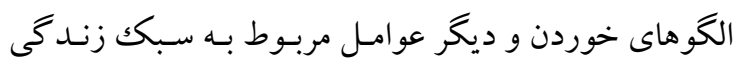
خطر جاقى را بالا ببرند. بطوريكه محروميت از خواب ممكن

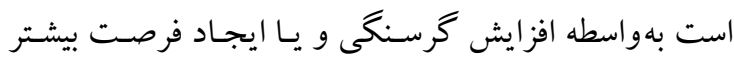


ببرد (V). از آنجا كه آمارهاى موجود در كشورمان حاكى از افزايش رو به رشد جاقى در همه گروههـاى سـنى و بـهويـزه جوانان مىباشد و جاقى داراى عـوارض جبـران نإِـذيرى بـر روى وضعيت سلامت افراد اسـت كـه بـه نوبـه خـود تبعـات اقتصادى و اجتماعى فراوانى به دنبال دارد، بايستى روشهاى

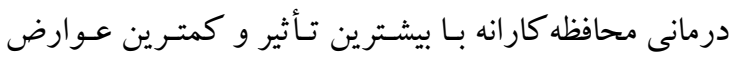

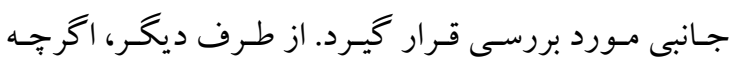
ارتباط بين خواب و جاقى مشخص شده و ارتباط بين جاقى بردي با شاخص هاى سـاختارى و عملكـردى قلب نيـز قبلاً مـورد

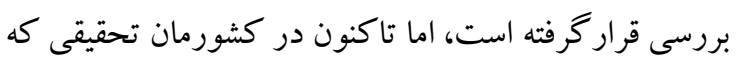

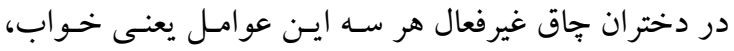

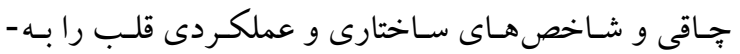
صورت يكجا و همزمان مـورد بررسى قـرار داده و در عين وسين

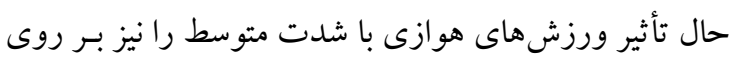

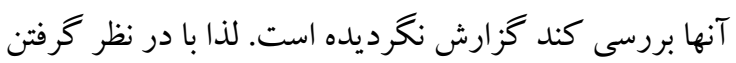

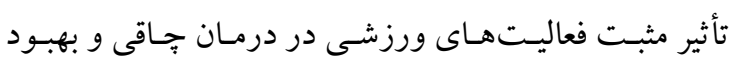
عملكرد قلبى عروقى از يكك سو و بهبود كيفيـت خـواب از

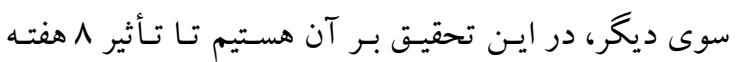
فعاليت ورزشى شدت متوسط را بر كيفيت خواب و ارتبـاط آن با تغييرات ساختارى و عملكردى قلب دختـران جـوان و

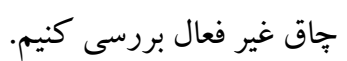

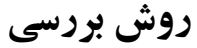
آزمودنىها

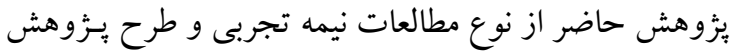

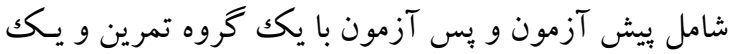

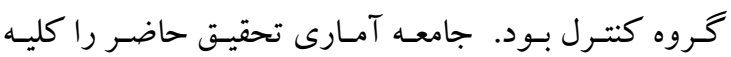

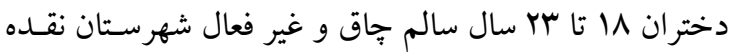
تشكيل مىدادند. معيارهاى ورود به تحقيق عبارت بودنــ از:

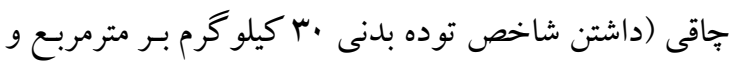
بالاتر)، عدم ابتلا بـه بيمـارىهـاى قلبى عروقى، كليوى و و

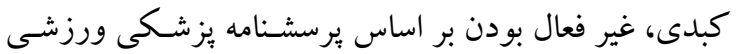

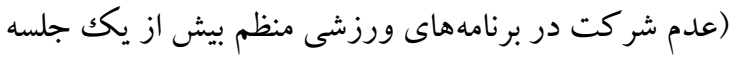

بيمارىهاى قلبى عروقى نمايد. همجنين، جديدترين تحقيتق

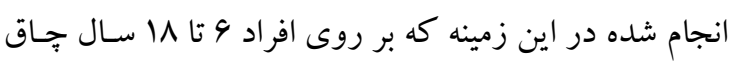

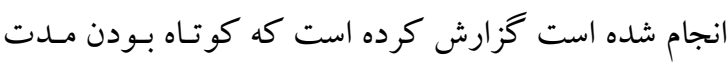
خواب احتمالاً تأثير مستقيم بر بازسـازى (Remodeling)

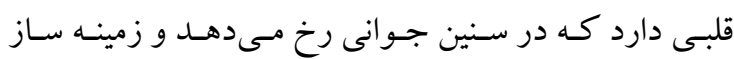
بيمارى هاى قلبى عروقى است (F).

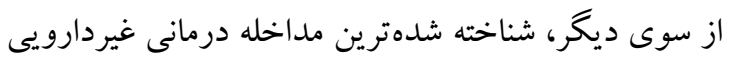

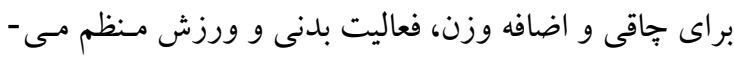

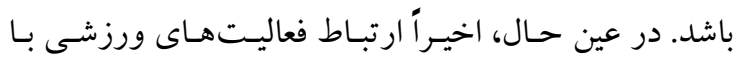
اختلالات خواب نيز مـورد بررسى قرار گرفته اسـت. نتسايج

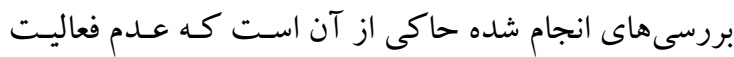
بدنى عاملى براى افزايش احتمال بروز علائمم بـىخـوابى يـا

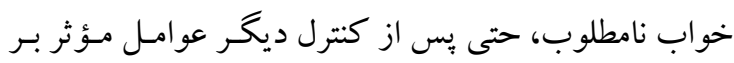

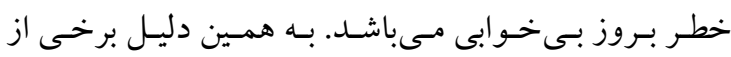

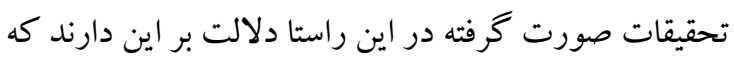

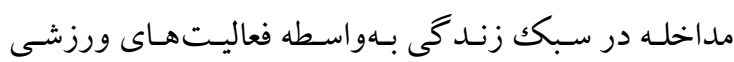
ممكن است كيفيـت خواب رادر افرادى كـه از مشكلات خواب رنج مىبرنــ بهبود دهــ (ه). بـهـورى كـه شـواهد

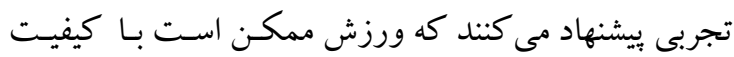

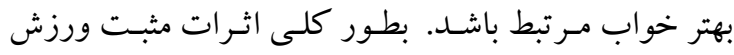

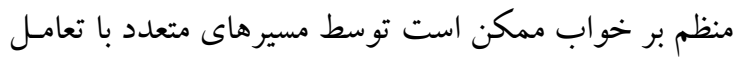
اثترات ريـتم شـبانه روزى، متابو ليكك، ايمنسى، تنظيم كنتـده حرارت، عروقى، خلقوخو و اندوكرين شرح داده شود (9).

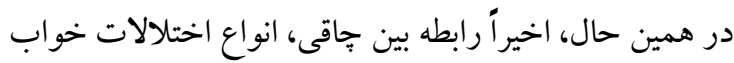

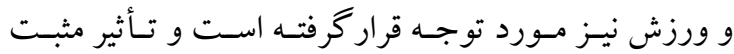

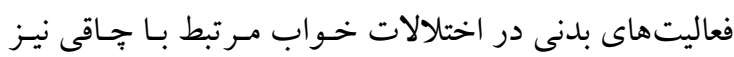

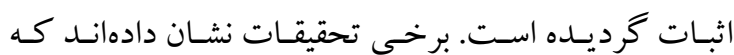
ورزش در افراد جاق علاوه بر تأثير بـر روى وزن و شـاخص لهص

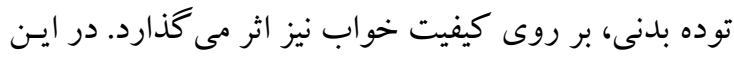

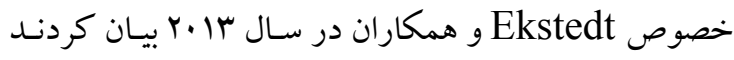

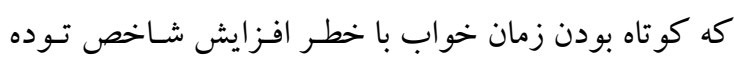

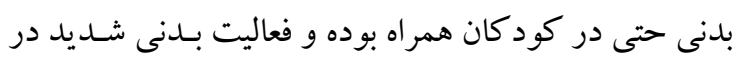

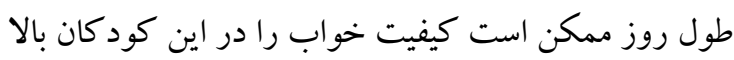


بر مجذور قد (مترمربع/كيلو گرم) محاسبه گرديـد. دور كمـر

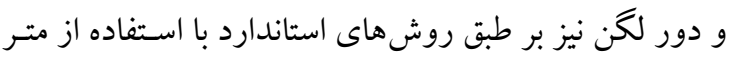
نوارى اندازه كيرى شدند.

\section{اندازهكيرى ضربان قلب استراحت و فشار خون}

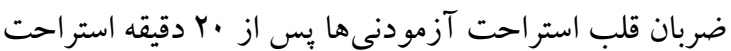
در حالت نشسته با استفاده از ضـربان سـنج ديجيتالى (مـدل فئل polar دياستولى از بـازوى راسـت و بـا استفاده از دستكاه ديجيتـال

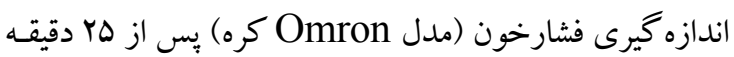
استراحت در حالت نشسته اندازه گيرى شد. اندازه گيرى فشار

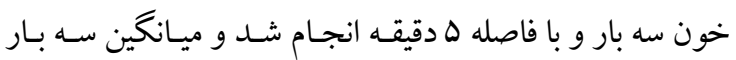

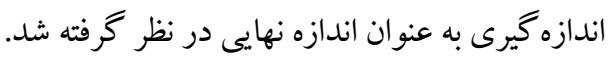

\section{اكو كارديوكر افى إنى}

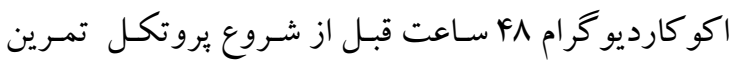

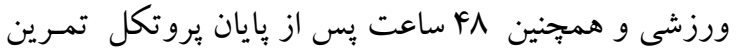

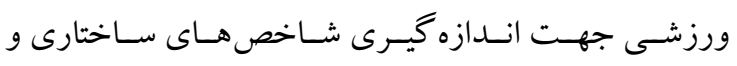
عملكردى قلب، توسط بز شكك متخصص قلب و عروق و بـا

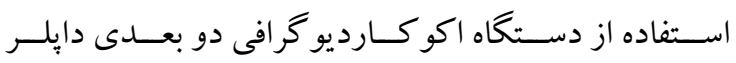
سـاخت كشور ايتاليـا) در اتـاق مخصوص اكو كارديو كرافى انجـام گرفـت. در ايـن تحقيـق

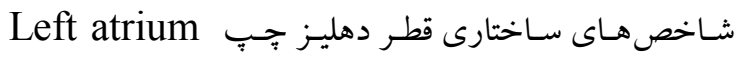

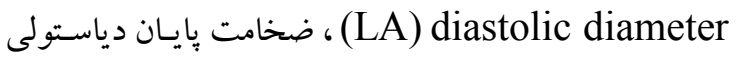
ديواره خلفى بطن جِب ،(LVPWd) wall thickness at end diastole

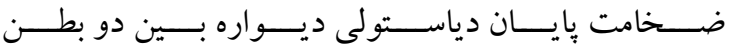
Interventricular septum thickness at end Left ابعـاد بايـــان دياسـتولى (IVSd) diastole (LVDd) ventricle diastolic dimension سيستولى Left ventricle systolic dimension بطن جִ و شاخص هاى عملكردى حجم ضربه - (LVDs) اى Stroke volume) ، بـرون ده قلبى Strardiac

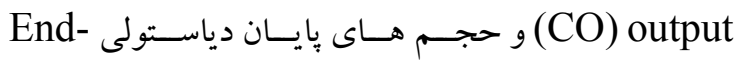
و و پايـان سيستولى (EDV) diastolic volume
در هفته در طى شش ماه گذشته)، كمتر از · ادرصـد تغييـر در وزن بدن در طول يـك سـال كذشـته، عـدم شـركت در

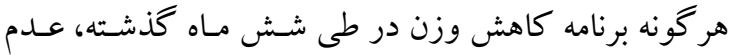

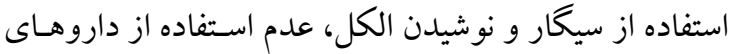

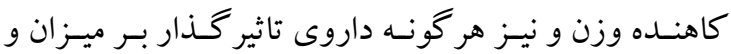

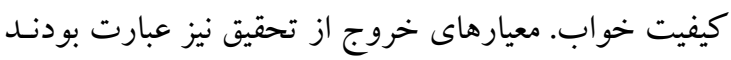

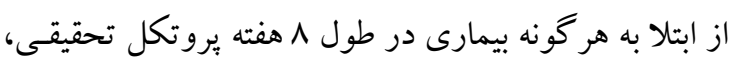
هر گونه دارو درمانى و رزيم غذايى و نيز عدم شر كت مـنظم

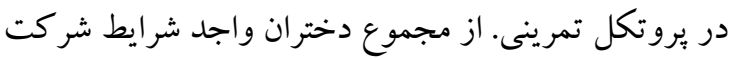

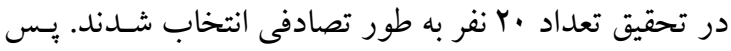
از انتخاب آزمودنىها كليه مراحل يزٔوهش بطور كامل براى نهاى

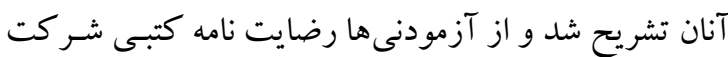

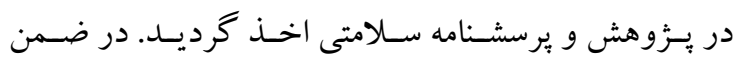
آزمودنىها مجاز بودند در هر زمان و بنا به هر دليل كه مايل

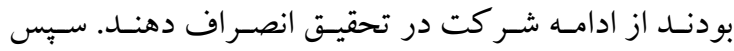
آزمودنىها بطور تصـادفى بـه دو گرووه تمـرين ( •انفـر ) و كنترل ( •انفـر ) تقسيم شــند. بـ روز قبـل از شـروع برنامـهـ تمرينى و بهدنبال r ا سـاعت وضسعيت ناشـتا از آزمهودنى هـا اندازه گيرىهاى بيكر سنجى و تر كيب بدن (شامل قد، وزن،

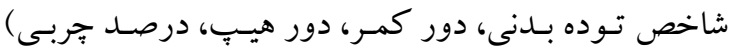
ضـبان قلب استراحت و فشـار خـون، اكو كـارديو گر افى و بررسى كيفيت خواب به عمل آمد و تمامى انـازه كيرىهـا

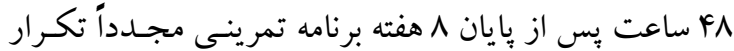
شد. از آزمودنىها خواسته شده بود كه سه روز قبل از انجام

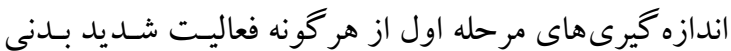
خوددارى كرده و رزيم غذايى عادى خود را حفظ كنند.

\section{اندازه كيرى شاخصهاى بيكرسنجى} قد و وزن آزمودنى ها به ترتيب با استفاده از دستخاه قدسنج با دقت / / • سانتيمتر و ترازوى ديجيتالى (Teka) (كميانى Bruer آلمان) با دقت ه/ • كيلو گرم انجام شـد.

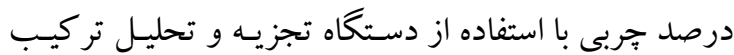

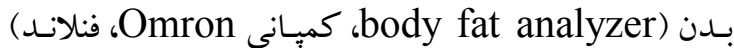
اندازهيرى شد. شاخص توده بدنى با استفاده از وزن تقسيم 
در ايسن فرمـول شـدت مـورد نظـر عبـارت اسـت از شـدت تمرينات بين •له تا ·V درصد حسداكثر ضـربان قلب تمـرين.

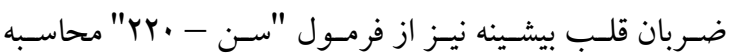
كرديد.

در تمام مدت انجـام تمرينـات ورزشـى، شـــت فعاليـت هـر آزمودنى توسط ضربان سنج يـلار كنتـرل مسى گرديـد. كليسه جلسات تمرين بين ساعت · ا تا با قبـل از ظهر تحـت نظر متخصص فيزيولوزى ورزش در سالن ورزشى بـا دمـاى هب-

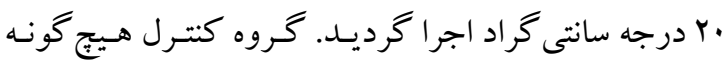
برنامه تمرينى انجـام نـداد و فعاليـت عـادى و برنامـه غـذايى معمول خود را ادامه داد. روش آمارى براى توصسيف دادههـا از آمـار توصسيفى (انحـراف معيـار ميانگين) استفاده شد. بس از تائيد نرمال بودن توزيع دادههـا

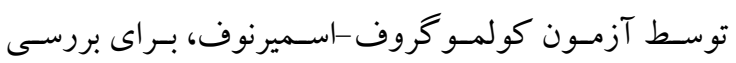

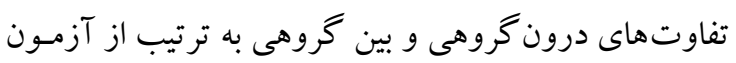
تى همبسته و تى مستقل استفاده گرديد. ارتباط بين متغيرهاى تحقيق نيز با استفاده از ضريب همبستخى بيرسون تعيين شـد. كليه داده ها با استفاده از نرم افزار SPSS نسخه سب تجزيه و تحليل شدند و سطح معنىدارى ه •/p در نظر خرفته شد.

\section{يافته ها}

نتايج تحقيق نشان داد كه در شـروع مطالعه بـين مشخصـات فردى، شاخصهاى آنترويومتريك و متغيرهاى فيزيولوزيك سك آزمودنى ها در دو گروه كنترل و تمـرين تفـاوت معنى دارى لـى وجود نداشت (جـدول (). هـمج جنسين در شـروع مطالعه بـين شاخص كيفيت خواب و شاخص هاى ساختارى و عملكردى قلب بين دو گروه كنترل و تمرين تفاوت معنى دارى مشاهده

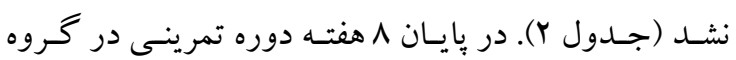
تمـرين، شـاخصهــاى وزن، شـاخص تـوده بــنى، انـدازه دور كمـر، انسـازه دور هيـبِ و ضـربان قلـب اسـتراحت در مقايسه با قبل از تمرين بطور معنى دارى كاهش يافتـه بودنـــ

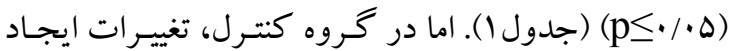

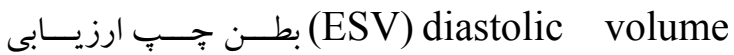
كرديدند.

\section{بروسى كيفيت خواب}

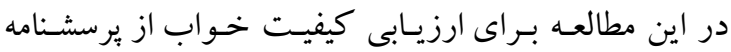

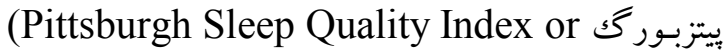
كـه يـك مقيـاس معتبـر و اسـتاندارد بـراى (^) PSQI) ارزشيابى كيفيت خواب و بررسى اختلالات خواب مىباشد استفاده شد. اين برسشنامه شامل 19 سؤال در مورد V جزء

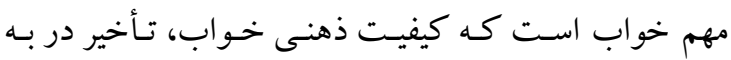
خواب رفتن، طول مدت خواب مفيد، كفايت خواب (نسبت طـول مـــت خـواب مفيـد از زمـان ســرى شــده در بسـتر)، اختلالات خواب (بيدار شدن شبانه)، ميـزان مصـرف داروى خوابآور و اختلال در عملكرد روزانه (مشككلات ناشى از بىخو ابى در طى روز) را مورد سنجش قرار مىدهد. به هـر جزء نمرهاى بين ب- · تعلق مى گيـرد و امتيـاز س در هـر جـزء

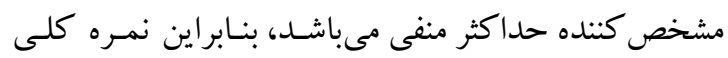
PSQI مناسب خواب است، در حالى كه نمره بين الY-9 بـه معنى كيفيت نامناسب خواب مىباشد.

برنامه تمرين هوازى برنامه تمرين هوازى در گروه تمرين، شامل تمرينات هوازى هوى شدت متوسط به مدت N هفته، هر هفته ب جلسه و هر جلسـه 94 دقيقه بود كه شـامل بيـاده روى تنـد، دويـدن و حركات ورزشى همراه با تحمل وزن بود. تمام جلسـات تمـرين بـا ده دقيقه گرم كردن و حركات كششى شروع شده و با ه دقيقـه سرد كردن به بايان مىرسـيد. ماهيـت تمـرين از نظـر شـدت

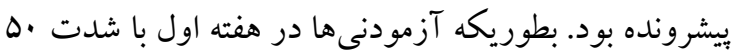
\% حـداكثر ضـربان قلـب، در هفتـه دوم بـا شـــت 90-9.9.

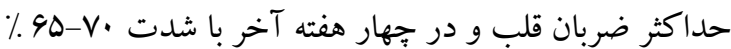
حداكثر ضربان قلب تمرين كردند. براى تعيين ضـربان قلب هدف تمرين، از معادله كارونن استفاده گرديد. ضربان قلب اسـتراحت + (ضـربان قلب اسـتراحت - ضـربان قلب بيشينه) × شدت مورد نظر = ضربان قلب فعاليت 


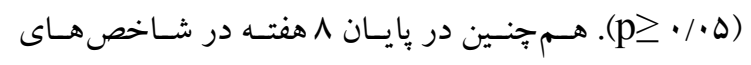
فوقالذكر بين دو گروه نيز تفاوت معنسىدارى مشـاهده نشـــ

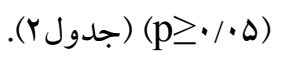

در شاخص هاى عملكردى قلـب (حجـم ضـربهاى، بـرون ده قلبى و حجمهاى بايان دياستولى و پايان سيستولى بطن جِب)

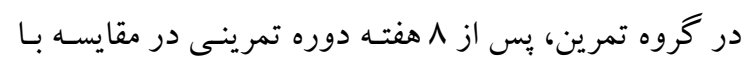

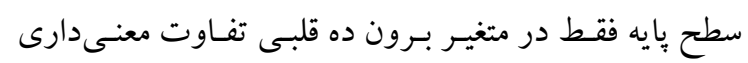

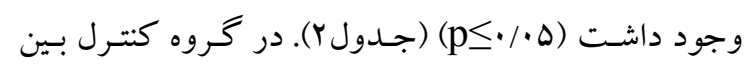
شاخص هاى عملكردى قلب در سطح بايـه و يسس از تمـرين

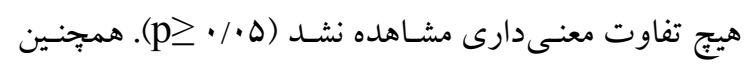

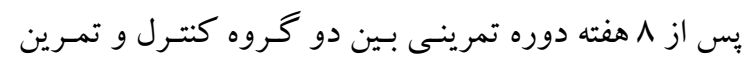
فقـط در متغيـر بـرون ده قلبـى تفـاوت معنسى دارى مشـاهده كرديد (p)
شده در شاخصهاى مذكور در مقايسه شرايط يايه با 1 هفته

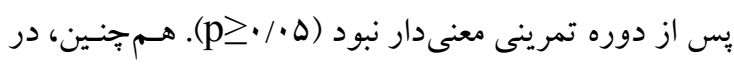
يايان م هفته دوره تمرينى تفاوت بين دو گروه در شـاخص هاى ذكر شده معنى دار بود (ه •/p نشان مسىدهـد كـه در يايـان \ هفتـه دوره تمرينـى شـاخص خواب در گروه تمرين نسبت به سطح بايه بطور معنسىارى نسى

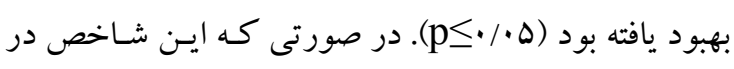

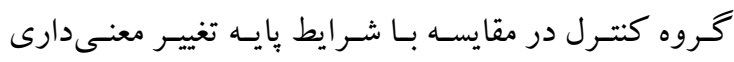
نداشت. علاوه بر اين، يس از ^ هفته دوره تمرينسى شـاخص

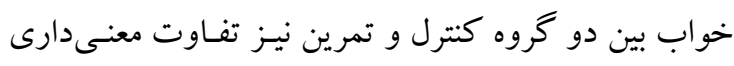

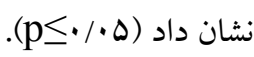
نتايج تحقيق حاضر نشان داد كـه در هـر دو گرـروه تمـرين و كنترل در شاخصهاى ساختارى قلب (قطر دياسـتولى دهليـز

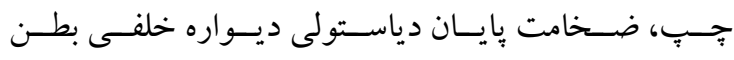
جֶֶٍ)

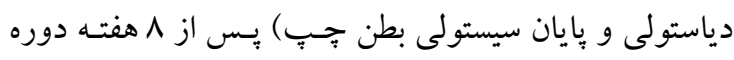
تمرينى نسبت به سطح پايه تفاوت معنى دارى وجود نداشـت

جدول ا: مقايسه مشخصات فردى، تركيب بدنى و متغيرهاى فيزيولوزيكك آزمودنى ها در دو گروه كنترل و تمرين قبل و پِ از ^هفته برنامه تمرينى

\begin{tabular}{|c|c|c|c|c|c|c|c|c|}
\hline \multicolumn{5}{|c|}{ كروه تمرين } & \multicolumn{3}{|c|}{ كروه كنترل } & \multirow[b]{2}{*}{ متغير } \\
\hline $\mathbf{P}^{\mathbf{c}}$ & $\mathbf{P}^{\mathbf{b}}$ & $\mathbf{P}^{\mathbf{a}}$ & گֶ از تمرين & قبل از تمرين & $\mathbf{P}^{\mathbf{a}}$ & پِ از تمرين & قبل از تمرين & \\
\hline$\cdot / \Delta \wedge r$ & $\cdot / \Delta \wedge r$ & - & $1 N / Y \cdot \pm 1 / V \Delta$ & $M / r \cdot \pm 1 / V \Delta$ & - & $1 N / 9 \cdot \pm 1 / 4 r$ & $1 N / 9 \cdot \pm 1 / 4 r$ & سن (سال) \\
\hline.$/ 9 V$ &.$/ 9 \vee$ & - & $\Delta \Delta Q / Y \cdot \pm \Delta / r V$ & $\Delta \Delta Q / r \cdot \pm \Delta / r V$ & - & $\mid \Delta Q / 4 \Lambda \pm 9 / \pi r$ & $109 / 1 \cdot \pm 9 / \pi r$ & قد (سانتيمتر) \\
\hline "**./. &.$/ 9 F Y$ & $* / \cdots 1$ & $q \Delta / v \cdot \pm|r /| \mid$ & $1 \cdot r / 1 \cdot \pm I r / r V$ &.$/ 194$ & $1 \cdot r / \Lambda \cdot \pm \mid r / r \Delta$ & $1 \cdot r / 0 \cdot \pm 1 r / F 4$ & وزن (كيلوكرم) \\
\hline$* * * . * \Delta$ & ./VFV & $* / \cdots 1$ & $r V / \Delta V \pm \Delta / v 1$ & $r \cdot / \cdot \Delta \pm \Delta / \Delta r$ & - /AFT & $r N / q \cdot \pm 1 r / 9 q$ & $\Gamma \Lambda / \Delta \cdot \pm I r / \Lambda \Delta$ & شاخص $\begin{array}{r}\text { توده بدنى } \\
\left(\mathrm{kg} / \mathrm{m}^{2}\right)\end{array}$ \\
\hline$* * . / . \mu q$ &.$/ 9 F V$ & $* / \cdots 1$ & $Q F / r \cdot \pm \mid r / r r$ & $99 / \Lambda \cdot \pm|r / \Lambda|$ & . Mar & $99 / 9 \cdot \pm 1 r / 1$ & $99 / 1 \cdot \pm|r / \Lambda|$ & دور كمر (سانتى متر) \\
\hline$* * .1 .49$ & .1994 & $* / \cdot \cdot 1$ & $৭ 9 / q \cdot \pm q / \mu \psi$ & $1 \cdot r / q \cdot \pm 1 \cdot / r \Delta$ & . $/ \Delta Y F$ & $1 \cdot r / r \cdot \pm 9 / 4 r$ & $1 \cdot 1 / 1 \cdot \pm v / \Delta r$ & دور هيب (سانتى متر) \\
\hline$* * * / r \Delta$ & $\cdot / \cdot \wedge V$ & $* . / . F \Delta$ & $V N / A \cdot \pm F / Y q$ & $\Lambda r / 9 \cdot \pm r / 9$. & .1940 & $\wedge \varphi / \Delta \cdot \pm r / V 1$ & $\Lambda F / 1 \cdot \pm r / v r$ & $\begin{array}{r}\text { ضربان قلب استراحت } \\
\text { (bpm) }\end{array}$ \\
\hline .119 & $\cdot / \mathrm{VG}$ & $\cdot / r \Delta F$ & $\mid r r / \Delta \cdot \pm r / r V$ & $\mid r K / F r \pm r F / Q$. &.$/ M r$ & $|r F /| \cdot \pm r / \Delta \mid$ & $\mid r / 9 \cdot \pm \Delta / V$. & $\begin{array}{r}\text { فشارخون سيستوليك } \\
\text { (mm Hg) }\end{array}$ \\
\hline .1 .9 &.$/ I F F$ & •/MAG & $\wedge \Gamma / 9 \cdot \pm 1 / \Lambda 9$ & $\Lambda F / V \cdot \pm r / 1 \Delta$ & $\cdot / A \cdot \Delta$ & $\Lambda \varepsilon / r \cdot \pm F / F$. & $\Lambda \Delta / \Delta \cdot \pm \Delta / 1$ & 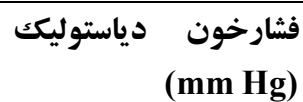 \\
\hline
\end{tabular}

مقادير بصورت انحراف معيار 土ميانگين نمايش داده شده اند.

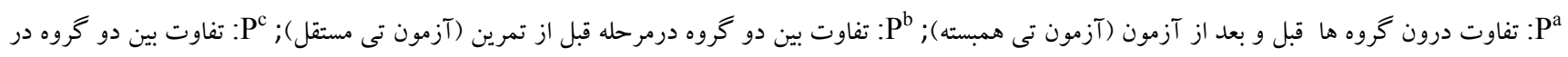

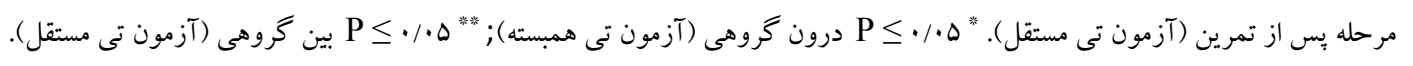




\begin{tabular}{|c|c|c|c|c|c|c|c|c|}
\hline & \multicolumn{4}{|c|}{ كروه تمرين } & \multicolumn{4}{|c|}{ كروه كنترل } \\
\hline $\mathbf{P}^{\mathbf{c}}$ & $\mathbf{P}^{\mathbf{b}}$ & $\mathbf{P}^{\mathbf{a}}$ & پِ از تمرين & قبل از تمرين & $\mathbf{P}^{\mathbf{a}}$ & صِ إ تمرين & قبل از تمرين & متغير \\
\hline . / $1 F a$ & - /VDI & $\cdot / 1 \wedge 1$ & $F I / r T \pm r r / l q$ & $r \mid / q) \pm q / F q$ & • MFY & $F r / W \pm Y I / q 9$ & $F r / V \cdot \pm r / / F q$ & $(\mathbf{m m}) \mathbf{L A}$ \\
\hline.$/ 9 V^{4}$ & ./9r. &.$/ 9 \Delta r$ & $N / \cdot 1 \pm 1 / 4$. & $V / ৭ ৭ \pm 1 / Y V$ & $\cdot / M F r$ & $N / \cdot 1 \pm 1 / 4$. & $V / A I \pm 1 / r V$ & (mm)LVPWd \\
\hline$\cdot / 9 F A$ & $\cdot / 9 W$ & $\cdot / \mathrm{AVA}$ & $V / \cdot V \pm 1 / \cdot \Lambda$ & $V / 11 \pm 1 / \Delta 9$ & - MEY & $V / 11 \pm 1 / \Delta 4$ & $V / \backslash \wedge \pm 1 / \Delta 1$ & $(\mathrm{~mm})$ IVSd \\
\hline . TKF & - /AQF & - /rrq & $k q / r) \pm q / 1$. & $F Y / M \Lambda \pm I r / \Delta \Delta$ & - MFY & $F Y / M \pm I r / \Delta \Delta$ & $F r / \Lambda 9 \pm \mid r / \Delta r$ & (mm) LVDd \\
\hline$\cdot / 49 \Delta$ & - / QVY & $\cdot / r 19$ & $r r / \Delta \cdot \pm F / r \Delta$ & $r \cdot / .1 \pm v / q$. & $\cdot / \mu k r$ & $r Y / F q \pm F / r \Delta$ & $r Y / V \Delta \pm F / Y q$ & $(\mathrm{~mm})$ LVDs \\
\hline .1 .94 & - NGF & - MTO & $\Delta q / Y q \pm I V / q Y$ & $\Delta . / 9 \Lambda \pm 1 . / 9$. & $\cdot / N F \Delta$ & $\mid \mathrm{VV} / .9 \pm 9 / \mathrm{rq}$ & $F V / N F \pm \mid r / F V$ & (ml) SV \\
\hline$* / . .1$ & . /AYY & $* / \cdots$ & $\Delta / \Delta \cdot \pm 1 / r q$ & $r / 19 \pm \cdot / 91$ & $\cdot / / V^{k}$ & $r / F \Lambda \pm 1 / \cdot q$ & $r / q V \pm \cdot / q$. & (ml) $\mathrm{CO}$ \\
\hline$\cdot / 1999$ & $\cdot / \Delta F$. & $\cdot / 149$ & $\| K / Y Y \pm \Lambda / A 1$ & $\|r / g r \pm V /\| r$ & $\cdot \pi k r$ & $1 / r / 9 Y \pm V / N T$ & $\| Y / V Y \pm V / I V$ & (ml) EDV \\
\hline .1944 & . /9VD & $\cdot / r F F$ & $94 / 94 \pm 9 / 90$ & $99 / 94 \pm 1 / 19$ & - MEY & $99 / 94 \pm 1 / 99$ & $99 / 0 \pm 9 / \cdot \Delta$ & (ml) ESV \\
\hline 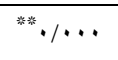 & .1190 & $* / \ldots$ & $9 / r \cdot \pm 1 / N$. & $11 / 9 \cdot \pm 1 / 81$ &.$/ 091$ & $I r / r \cdot \pm I / A r$ & $I r / r \cdot \pm I / N \Delta$ & كيفيت خواب \\
\hline \multicolumn{4}{|c|}{ 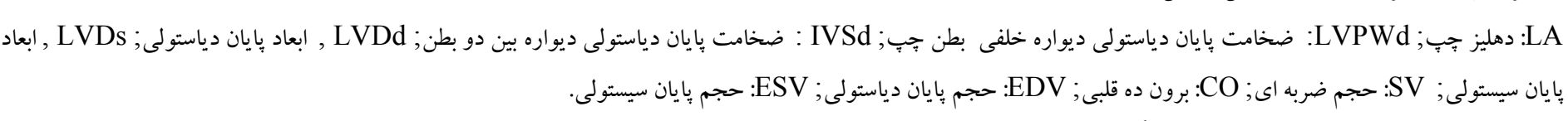 } & 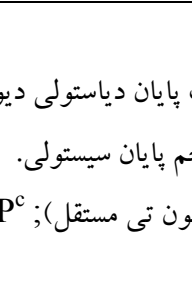 & & 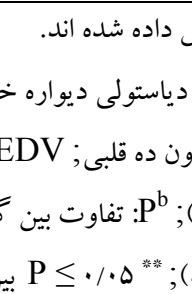 & 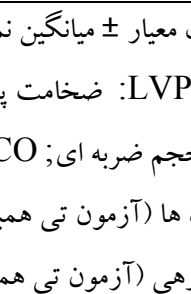 & 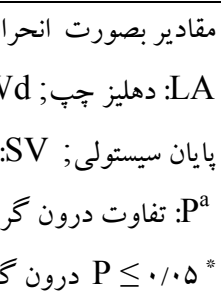 \\
\hline
\end{tabular}


براى كسانى كه كيفيت خواب نامناسـبى دارنـد باشــ (Y) (I). اثــرات سـودمند فعاليـت ورزشـى مـنظم بـر كيفيـت خـواب مىتواند توسط عواملى نظير تأثير ورزش در تنظيم دما (II)، تأثير بر عملكرد قلبى و اتونوميكك (IF)، تأثير بـر عملكرد اندوكرين و متابوليـك (ها)، تـأثير بـر پياسـخ هـاى ايمنسى التهابى (19) و نيسز تـأثير بـر خلـق و خـو مانــد افسردخى و اضطراب (IV) شرح داده شود. در ايسن راستا نتـايج بدست آمده از تحقيقات انجام شده در اين زمينه تمرينات هوازى با شدت متوسط را جهـت درمـان يـا بيشـخيرى از اخـتلالات خواب توصيه مى كند. با اين حال، تمرينات هوازى با شـدت بالا و تمرينات مقاومتى شدت متوسط جنين مزايايى به همراه ندارند. در تحقيق حاضر وزن و شاخص توده بـدنى آزمـودنىهـا در كروه تمرين بِ از ^ هفته برنامه تمرينسى بطور معنى دارى كاهش يافته بود. در همين راسـتا تحقيقـات اخيـر نيـز رابطـه معكوس و معنى دار بين خواب كو تـاه و خـواب نامناسـب بـا افز ايش شاخص توده بدنى را گَزارش كرده انسـ. همجنـين وجود ارتباط بين كيفيت و كميت خواب با كاهش وزن در افراد جاق و يا دار ایى اضافه وزن شركت كننده در برنامههاى مداخلهاى كاهش وزن كزارش شـده اسـت (1) ). بطوريكـه كيفيت و كميت بالاى خواب در اين افراد با احتمـال بـالاى موفقيـت در برنامـه كـاهش وزن همـراه بـوده اسـت. از ايسن ارتباط جنين بر مى آيد كه خواب در تنظيم وزن بــن نقـش

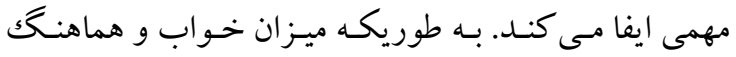
سازى ساعت بيولوزيكى هر دو براى دسـت يـابى بـه تعـادل انرزى و ترشح هورمونهاى تنظيم كننده وزن بدن ضسرورى مى باشـند. همجنـين مسى تـوان رابطهـ بـين سـاعت خـواب و تغييرات وزن بدن را به عوامل هورمونى نسبت داد. بطوريكه تحقيقات نشان داده است كه در افراد جوان و سـالم كـاهش طول مدت خواب با كاهش سطوح لِيتين (هورمون سـيرى)، افزايش سطوح كر لين (هورمـون محـرك اشـتها) و افزايش
خواب بـراى يـك زنـدگى سـالم و نرمـال ضـرورى بـوده و فقدان خواب مناسب بر عملكرد فيزيكى، ذهنى و هيجـانى فرد تأثير مى كذارد. هدف از تحقيق حاضـر بررسى تـأثير هفته تمرينات هـوازى شـدت متوسط بـر كيفيـت خـواب و ساختار و عملكرد قلب در دختران جاق غير فعال بود. نتـايج تحقيق حاضر نشـان داد كـه م هفتـهـ تمـرين هـوازى موجـب بهبود كيفيت خواب در دختران جاق غيـر فعـال كرديـد كـه هم راستا با ساير تحقيقات انجام شده در اين زمينه مىباشد و بر تأثير مثبت ورزشهاى هـوازى در بهبـود كيفيـت خـواب افراد با وزن عادى و نيـز افـراد جـاق و يـا داراى اضـافه وزن دلالت دارد (9). اكر خه نتايج تحقيقات در مورد تأثير مثبـت ورزش حاد در بهبود مشـكلات خـواب بـه دليـل متغيرهـايى همجون زمان ورزش در طول روز تا حدى متناقض مىباشد، اما تمرينات منظم ورزشى به عنوان يـك درمـان غيردارويسى شخفت آور براى مشكلات خواب معرفى شده اسـت. نتـايج مقاله مرورى انجام شده توسط Kubitz نشان مىدهـد كـه ورزش منظم خـواب Rapid eye movement (خـواب همراه با حر كـات سـريع جشــم يـا خـواب فعـال كـه در ايـن مرحله ضربان قلب تند تر و متابوليسم مغـزى بــ انـــازه زمـان بيدارى اسـت)، تـأخير در شـروع خـواب و بيـدارى يسس از شروع خواب را كاهش مىدهد و در عين حسال، خـواب بـا امواج آهسته يا Non-rapid eye movement (در ايـن مرحله ضربان قلب يايين بوده و متابوليسم مغـزى بطور قابـل توجهى كاهش مى يابد) و كل زمان خواب را افزايش مسى -

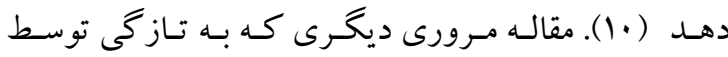
Rubio و همكاران در سال Y. V منتشر شده است نيز تأثير مثبت فعاليتهاى ورزشى هوازى را در بهبود كيفيت خواب اثبات كرده است (11). همجنـين جديـدترين تحقيـق انجـام شده در خصوص ورزش و اختلالات خواب، بيشـنهاد مسى - شئ كند كه خواب و ورزش اثرات مثبـت و سـودمندى بـر روى يكديكر دارند و فعاليت ورزشى مىتواند يكك مداخله مـؤثر 
نتايج ديكر تحقيقـات انجـام شـده در ايـن خصـوص همسـو نمىباشد. به عنوان نمونه، Cicek و همكاران در سـال كزارش كردند كه در زنان داراى اضافه وزن 19 هفته تمرين

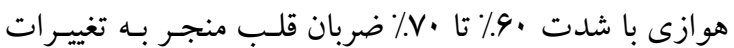
معنسى دار در شـاخص هــاى سـاختارى قلـب (ابعـاد يايــان دياستولى بطن جٍِ، ضخامت ديواره بين دو بطن و ضخامت

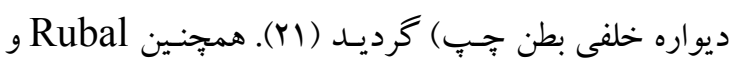
همكاران درسـال 1991 تغيـرات معنى دار در شـاخصهـاى سـاختارى قلـب (ابعـاد بايسان دياسـتولى و ضـخامت ديـواره خلفى بطن جِب) را بهدنبال •ا هفته تمرين دويـدن در زنـان كزارش كردند (YY). از آنجايى كه ثابت شده است تغييرات ساختارى قلب بهدنبال ورزش به عو املى مانند نوع، شـدت و

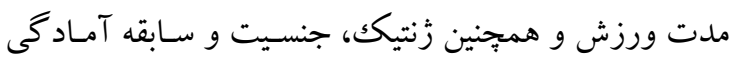

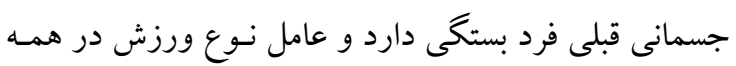
تحقيقات انجام شده مشابه و از نوع هوازى بوده است، به نظر مىرسد كه محتمل تـرين علـت عـدم تغييـرات سـاختارى در قلب آزمودنىهاى تحقيق ما مىتواند مدت و شدت ناكافى ورزش باشد. لذا به نظر مسىرســ كـه هـر جـه دوره تمرينى كوتاهتر باشد، براى ايجـاد تغييـرات مورفولوزيـك در قلـب شدت ورزش بايستى بالاتر باشد. از طرفى تحقيقات مشخص

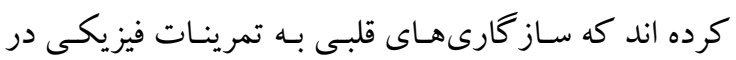
افراد غيرفعال كمتر واضح است. لذا از آنجايى كه افراد جاق به دليل وزن زياد تحرك كمترى نسبت به افراد غير فعـال بـا وزن معمولى دارند، ايسن سـابقه كـم تحركى نيز مسى توانــ عاملى براى عـدم تغيــردر شـاخصهـاى سـاختارى قلب در باسخ به \ هفته تمرين باشد. در كل با توجه به موارد مطرح شده مىتوان نتيجه كرفت كه برنامه هـوازى اعمـال شـده در

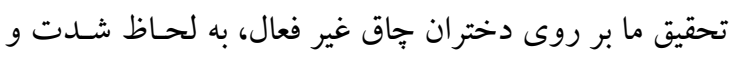
مدت توانايى لازم جهت تغيير در ابعاد بطن جـبِ و ديـواره خلفى بطن جٍِ را نداشته است. در رابطه با شاخصهاى عملكردى قلب، نتايج تحقيق حاضر نشان داد كه ^ هفته تمـرين هـوازى فقـط شـاخص بـرون ده قلبى را نسبت به سطح يايه بطور معنىدارى تغيير داد كه ايسن
اشتها و گرسنگى همر اه مىباشد. ما در اين تحقيق ارتباط بين كيفيـت خــواب بـا وزن و شـاخص تـوده بــنـى را بررسـى نكرديم، اما از آنجه كفته شد نتيجه كيرى مىشود كه كاهش وزن و شاخص توده بدنى از عوامل مـؤثر بـر بهبـود كيفيـت خو اب در اين تحقيق بوده است. در رابطه با شاخص هاى ساختارى قلب، نتايج تحقيق حاضـر

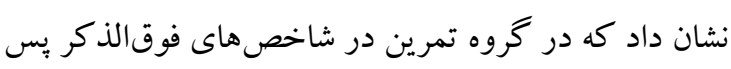
از A هفته دوره تمرينى نسبت به سطح بايه تفاوت معنىدارى

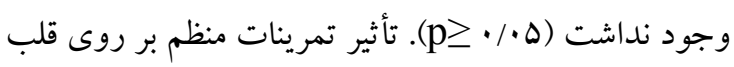
مدت هاست كه بطور گسترده مورد بررسى قرارگرفته اسـت و شواهد متعـدد مو جـود در ايسن زمينـه نشـان مسىدهنــ كـهـ تمرينات هوازى منجر به ساز گارىهاى مطلوب سـاختارى و عملكردى در قلب شده و ايسن سـاز كارىهـا موجـب بهبـود كار آيى قلب در افراد سـالم و نيسز بيمـار ان قلبى مسى گرددد.

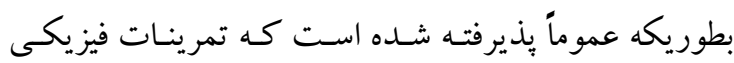

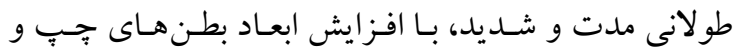
راسـت و افزايش ضـخامت ديـواره بطـن جـبِ هـاييرتروفى متعادل قلبى را تحريك مى كند. با اين حال، نتايج تحقيقـات انجـام شـده در ايسن خصـوص تـا حسدى متفــاوت هسـت. بطوريكه برخى تحقيقات هيج تغييـرى در ابعـاد قلب تحـت

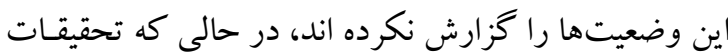

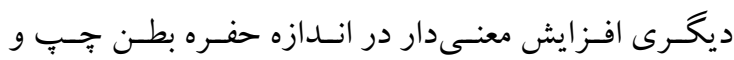

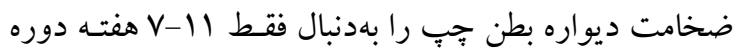
تمرينى گز ارش كرده اند. نتيجه تحقيق ما همراسـتا بـا نتـايج بدست آمده از تحقيت Wolfe و همكاران در سـال 1999 مىباشد كه عدم تغيير در شاخصهاى سـاختارى قلب را در زنـان غيـر فعـال شـركت كنــــه در يـكك برنامـه ال هفتـهاى

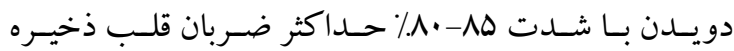
كزارش كردند (19). همجيجنين نتايج ايسن يـروهش همسـو بـا نتايج تحقيق Hulke و همكاران در سال II إr مىباشد كه عدم تغيير در شاخصهاى ساختارى قلب را بـدنبال r إهتـه تمـرين هـوازى دويسـدن در زنـان و مـردان شـركت كنتـده

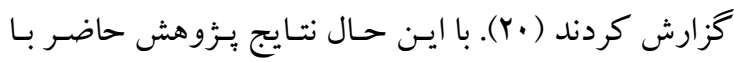


در رابطه با شاخص هاى عملكردى حجـم يايـان سيستولى و

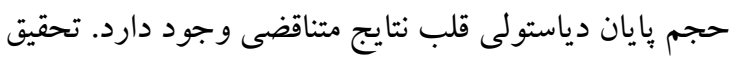

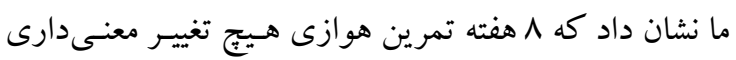

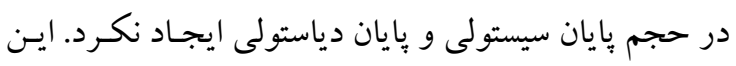

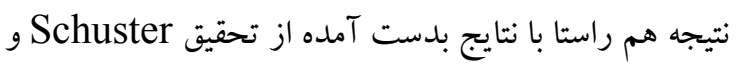

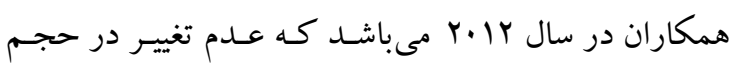

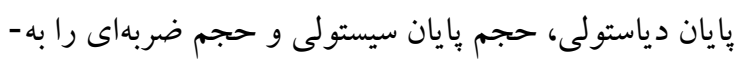

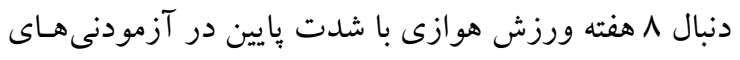
نسبتاً جاق گزارش كردند (Y4). با اين حسال در تحقيق آنها ديخر شاخص هاى نشان دهنده عملكرد دياستولى و عملكرد سيستولى يـس از ^ هفتـه ورزش هـوازى بهبـو معنى دارى

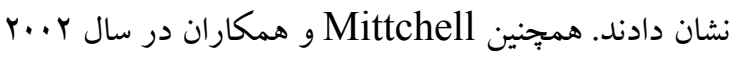
نتوانستند هيج تغييرى در شاخص هاى ساختارى قلب را بـهدنبال 1 ماه ورزش هوازى با شدت متوسط و زياد در جوانان جاق ييدا كنند (YV). با اين حال اين نتيجه در تضاد بـا نتيجـه تحقيق Vogelsang و همكاران در سال ^+.r مىباشد كه افزايش حجم پايان دياستولى و افزايش حجم ضـربهاى را بدنبال م هفته ورزش دويدن با شدت متوسط در آزمودنى -

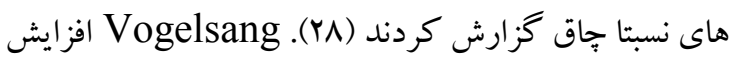

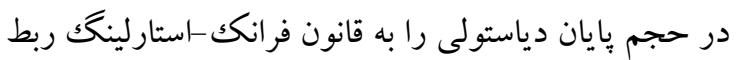
داده و اضافه كرد كـه افزايش بـيش بـار قلبى در باسـخ بـهـ

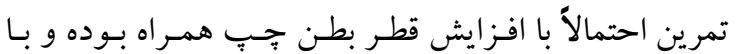
كشـش ديـواره و ايجـاد رفلكس هـايير تروفى اكسـتريكك

$$
\text { استرس بر ديواره را كاهش مىدهد. }
$$

نتايج تحقيق حاضر نشان داد كه يك برنامه م هفتهاى تمرين

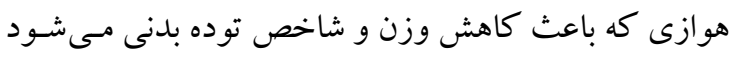

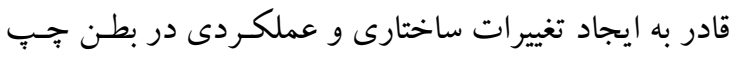

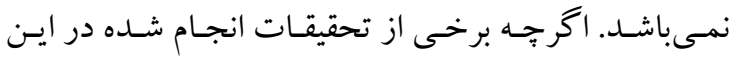

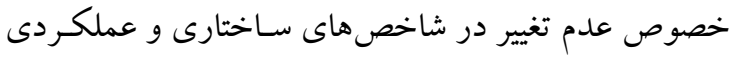

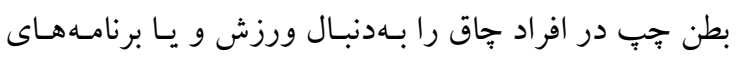

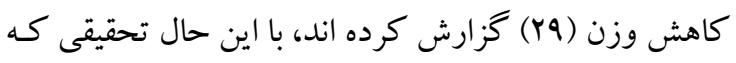

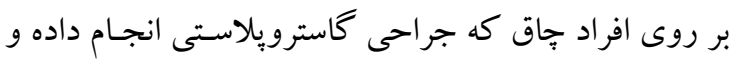

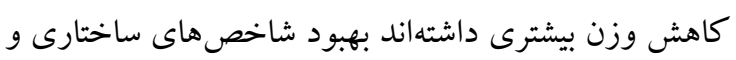

تغيير در گروه كنترل معنىدار نبود. بطور كلى ساز گارىهاى

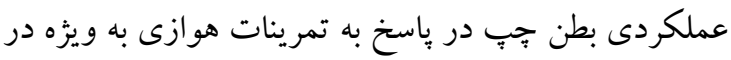

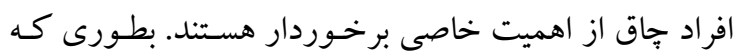
يافتهاى اخير بيشنهاد مى كند كه تمرينات هوازى به تنهايى براي

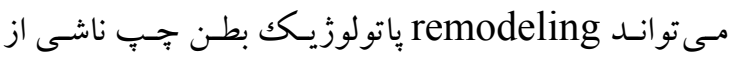

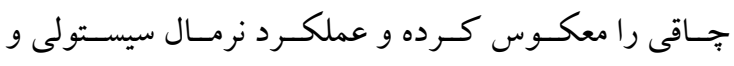

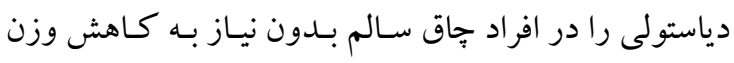
بدن بهواسطه محدوديت كالرى بر گرداند. اين يافته مى تواند

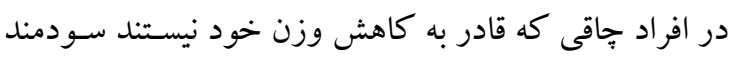

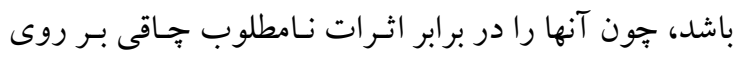

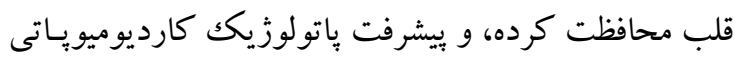

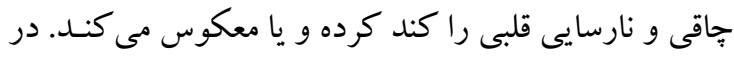

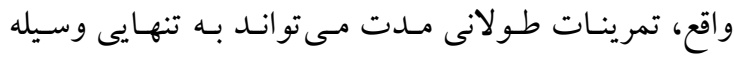
مؤثرى براى محافظت و حتى بهبود عملكرد قلبى بدون نيـاز به كاهش وزن بهواسطه تغييرات غذايى در افراد جاق باشـــ.

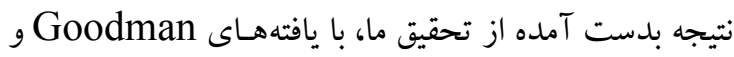

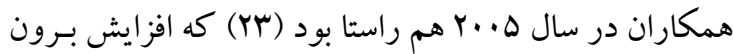

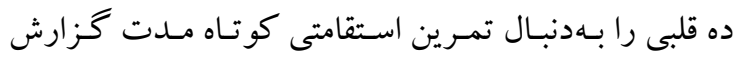

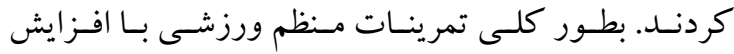

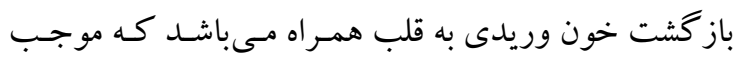

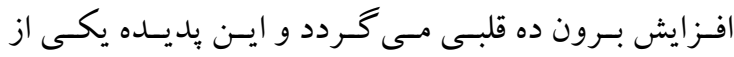

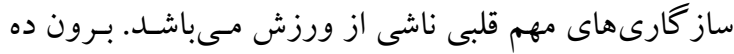

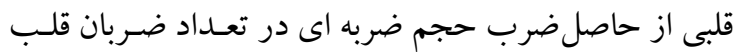
محاسبه مى شود و در تحقيـق مـا حجم ضـربهاى بطور غير معنى دارى افزايش يافته بود. اما Obert و همكاران در سـال

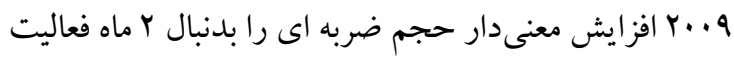

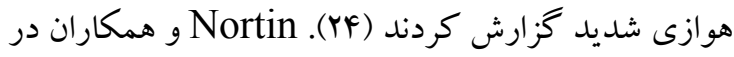
سال r ... نيز افزايش غيرمعنى دار حجم ضـربهاى را بـدنبال

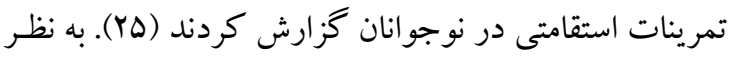

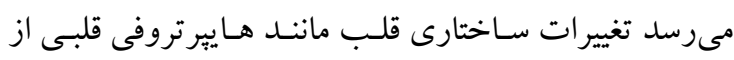

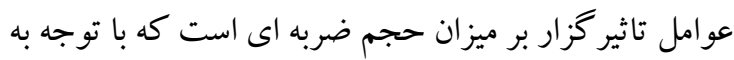

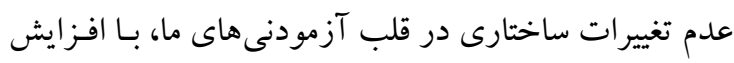
غير معنى دار حجم ضربهاى مواجه شدهايم. 
درصد حداكثر ضربان قلب منجـر بـه تغيـرات سـاختارى و عملكردى بطن جِّ مسىشـود. لـذا در تحقيـق حاضـر بـايين بودن شدت ورزش و يا كمتر بودن هزينه انرزى صرف شده در هر جلسـه مسىتوانـد يكى از دلايـل مهـم عـدم تغييـرات مطلوب در ساختار و عملكرد قلب باشد.
عملكردى بطن جِب را نشان داده است (·r). بنابر اين به نظر

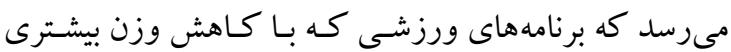
همراه باشند و مدت زمان بيشترى طول بكشند احتمال بالايى دارد كه منجر به تغيير سـاختار و عملكـرد بطن جـبِ شـود.

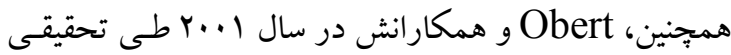

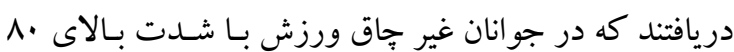

\section{نتيجه كيرى}

بطور كلى نتايج تحقيق حاضر نشان داد كـه 1 هفتـه فعاليـت

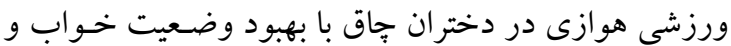
كاهش وزن و شاخص توده بدنى همراه بوده و موجب بهبود

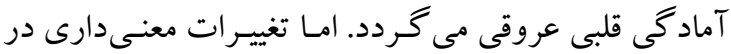

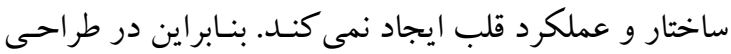
برنامهاى ورزشى براى دختـران جـاق جـوان جهـت ايجـاد تغييرات مطلوب قلبى از نظر ساختار و عملكرد بايستى شدت و مدت ورزش و هزينه انرزى صرف شده در هر جلسه بطور دقيق مورد توجه قرار گيرد.

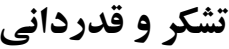

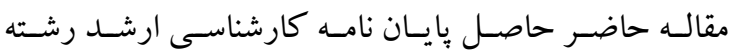
فيزيولوزى ورزشى خانم مرضيه اجلالى در دانشـاه اروميه

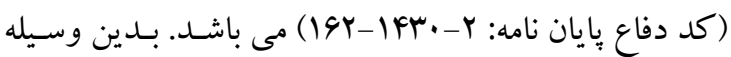

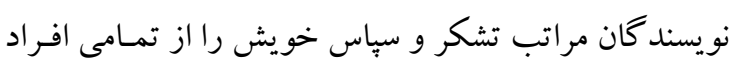

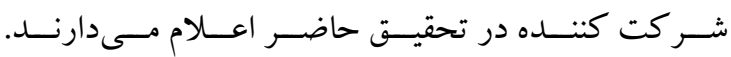




\section{Reference}

1. Patel SR, Blackwell T, Redline S, Ancoli-Israel S, Cauley JA, Hillier TA, et al. The association between sleep duration and obesity in older adults. Int J Obes 2008;32:1825-34.

2. Patel SR, Hu FB. Short sleep duration and weight gain: a systematic review. Obesity (Silver Spring) 2008;16:643-53.

3. Chaput JP, Despres JP, Bouchard C, Tremblay A. Short sleep duration is associated with reduced leptin levels and increased adiposity: Results from the Quebec family study. Obesity (Silver Spring) 2007;15:253-61.

4. Feng D, Zhang J, Fu J, Wu H, Wang Y, Li L, et al. Association between sleep duration and cardiac structure in youths at risk for metabolic syndrome. Sci Rep 2016;6:39017.

5. King AC, Pruitt LA, Woo S, Castro CM, Ahn DK, Vitiello MV, et al. Effects of moderateintensity exercise on polysomnographic and subjective sleep quality in older adults with mild to moderate sleep complaints. J Gerontol A Biol Sci Med Sci 2008;63:997-1004.

6. Chennaoui M, Arnal PJ, Sauvet F, Leger D. Sleep and exercise: a reciprocal issue? Sleep Med Rev 2015;20:59-72.

7. Ekstedt M, Nyberg G, Ingre M, Ekblom O, Marcus C. Sleep, physical activity and BMI in six to ten-year-old children measured by accelerometry: a cross-sectional study. Int J Behav Nutr Phys Act 2013;10:82.

8. Buysse DJ, Reynolds CF, 3rd, Monk TH, Berman SR, Kupfer DJ. The Pittsburgh Sleep Quality Index: a new instrument for psychiatric practice and research. Psychiatry Res 1989;28:193-213.

9. Tan X, Alen M, Wiklund P, Partinen M, Cheng S. Effects of aerobic exercise on homebased sleep among overweight and obese men with chronic insomnia symptoms: a randomized controlled trial. Sleep medicine 2016;25:113-21.

28. Moreno-Vecino B, Arija-Blazquez A, Pedrero-Chamizo R, Gomez-Cabello A, Alegre LM, Perez-Lopez FR, et al. Sleep disturbance, obesity ,physical fitness and quality of life in older women: EXERNET study group. Climacteric 2017;20:72-9.

10. Kubitz KA, Landers DM, Petruzzello SJ, Han M. The effects of acute and chronic exercise on sleep. A meta-analytic review. Sports Med 1996;21:277-91.

11. Rubio-Arias JA, Marin-Cascales E, Ramos-Campo DJ ,Hernandez AV, Perez-Lopez FR. Effect of exercise on sleep quality and insomnia in middle-aged women: A systematic review and meta-analysis of randomized controlled trials. Maturitas 2017;100:49-56.

12. Dolezal BA, Neufeld EV, Boland DM, Martin JL, Cooper CB. Interrelationship between Sleep and Exercise: A Systematic Review. Adv Prev Med 2017;2017:1364387.

13. Murphy PJ, Campbell SS. Nighttime drop in body temperature: a physiological trigger for sleep onset? Sleep 1997;20:505-11.

14. Sandercock GR, Bromley PD, Brodie DA. Effects of exercise on heart rate variability: inferences from meta-analysis. Med Sci Sports Exerc 2005;37:433-9.

15. Scheen AJ, Byrne MM, Plat L, Leproult R, Van Cauter E. Relationships between sleep quality and glucose regulation in normal humans. Am J Physiol 1996;271:E261-E70.

16. Uchida S, Shioda K, Morita Y, Kubota C, Ganeko M, Takeda N. Exercise effects on sleep physiology. Front Neurol 2012;3:48.

17. Paluska SA, Schwenk TL. Physical activity and mental health: current concepts. Sports Med 2000;29:167-80. 
18. Thomson CA, Morrow KL, Flatt SW, Wertheim BC, Perfect MM, Ravia JJ, et al. Relationship between sleep quality and quantity and weight loss in women participating in a weight-loss intervention trial. Obesity (Silver Spring) 2012;20:1419-25.

19. Wolfe LA, Laprade A, Burggraf GW, Norman R. Cardiac responses of young women to conditioning for a 10 kilometer race. Int J Sports Med 1992;13:384-9.

20. Hulke SM, Phatak MS. Cardiac adaptation to endurance training in young adult. Chronicles of Young Scientists 2011;2:103.

21. Cicek G, Imamoglu O, Gullu A, Celik O, Ozcan O, Gullu E, et al. The effect of exercises on left ventricular systolic and diastolic heart function in sedentary women: Step-aerobic vs core exercises. J Exerc Sci Fit 2017;15:70-5.

22. Rubal BJ, Al-Muhailani AR, Rosentswieg J. Effects of physical conditioning on the heart size and wall thickness of college women. Med Sci Sports Exerc1987;19:423-9.

23. Goodman JM, Liu PP, Green HJ. Left ventricular adaptations following short-term endurance training. J Appl Physiol 2005;98:454-60.

24. Obert P, Nottin S, Baquet G, Thevenet D, Gamelin FX, Berthoin S. Two months of endurance training does not alter diastolic function evaluated by TDI in 11-9-year-old boys and girls. Br J Sports Med 2009;43:132-5.

25. Nottin S, Vinet A, Stecken F, N'Guyen LD, Ounissi F, Lecoq AM, et al. Central and peripheral cardiovascular adaptations to exercise in endurance-trained children. Acta Physiol Scand 2002; 175:85-92.

26. Schuster I, Vinet A, Karpoff L, Startun A, Jourdan N, Dauzat M, et al. Diastolic dysfunction and intraventricular dyssynchrony are restored by low intensity exercise training in obese men. Obesity (Silver Spring) 2012;20:134-40.

27. Mitchell BM, Gutin B, Kapuku G, Barbeau P, Humphries MC, Owens S, et al. Left ventricular structure and function in obese adolescents: relations to cardiovascular fitness, percent body fat, and visceral adiposity, and effects of physical training. Pediatrics 2002;109:E73-3.

28. Vogelsang TW, Hanel B, Kristoffersen US, Petersen CL, Mehlsen J, Holmquist N, et al. Effect of eight weeks of endurance exercise training on right and left ventricular volume and mass in untrained obese subjects: a longitudinal MRI study. Scand J Med Sci Sports 2008;18:354-9.

29. Reid CM, Dart AM, Dewar EM, Jennings GL. Interactions between the effects of exercise and weight loss on risk factors, cardiovascular haemodynamics and left ventricular structure in overweight subjects. J Hypertens1994;12:291-301.

30. Karason K, Wallentin I, Larsson B, Sjostrom L. Effects of obesity and weight loss on left ventricular mass and relative wall thickness: survey and intervention study. BMJ 1997;315:912-6. 